\title{
Diversified Housing Developments for Socio-Economic Integration in South Africa's Urban Human Settlements
}

\author{
Ms Tlou Ramoroka \\ University of Limpopo, Department of Development Planning and Management \\ Millicent.Ramoroka@ul.ac.za
}

\section{Doi:10.5901/mjss.2014.v5n25p44}

\begin{abstract}
This paper investigates the diversification of housing development in South Africa as a means to promote socio-economic integration in urban human settlements. The need to encourage the establishment and improvement of diversified housing developments in urban areas has been widely recognised as an appropriate measure to ensure that people from different social and economic groups share the same neighbourhoods. In South Africa, socio-economic diversity in towns and cities was introduced in the early 19th century as an attempt to put people from different backgrounds in one place in order to address the inequalities which existed as a result of the past settlement planning system. Furthermore, the strategy was meant to limit the degree of isolation that the poor are faced with due to the past urban planning in order to maintain community stability, social bond and cohesion within human settlements. Theoretically, the paper argues that socio-economic diversity of housing developments have the ability to promote economic integration, social cohesion and community stability in urban human settlements. The pragmatic effects of housing development diversity can be realised through measures such as densification, mixing of different building structures that accommodates people from different backgrounds and equal accessibility to infrastructure, amenities and services, among others. The paper concludes that socio-spatial diversity within urban housing developments can be used as strategy to bring together people from different social and economic backgrounds in order to address inequalities that are associated with segregation.
\end{abstract}

Keywords: Housing developments, Socio-economic integration, Diversity, Urban areas and South Africa

\section{Introduction}

In reaction to the continuous challenges posed by the past social and spatial segregation in current towns and cities, there has been an increasing call for greater socio-spatial integration and mix in housing developments and neighbourhoods in recent years (Ge \& Hokao, 2006; Jacobs \& Appleyard, 2007; Putnam, 2007; Talen, 2008; Denisova, Eller, Frye \& Zhuravskaya, 2012; Sharma, 2012; Gądecki, 2014). The socio-spatial integration is especially the case in South Africa, where fragmentation remains a major challenge within towns and cities (Christopher, 2004; Todes, Karam, Klug \& Malaza, 2010; Musakwa \& Van Niekerk, 2013; Kovács \& Hegedüs, 2014). South Africa's towns and cities have, since 1994, experienced varying degrees of socio-spatial transformation, which necessitates a reconsideration of the current status quo and the levels of diversity and integration or lack thereof in urban areas (Todes, Karam, Klug \& Malaza, 2010; Musakwa \& Van Niekerk, 2013; Güzey, 2014). It is argued that socially and spatially mixed developments and neighbourhoods can support place diversity and contribute to safer and more sustainable human settlements (Ge \& Hokao, 2006; Jacobs \& Appleyard, 2007; Putnam, 2007; Talen, 2008; Denisova et al., 2012; Sharma, 2012; Smigiel, 2014). One of the most significant factors changing the urban landscape in South Africa has been the increase of townhouse complexes or sectional title schemes. In South Africa, however, the concepts of diversity and integration are often used in a very broad sense, without common agreement of what this would entail in practice. What would it mean to say our neighbourhoods and housing developments are socio-economically diverse? Or on what do people base statements that there is a lack of integration within housing developments or within neighbourhoods? It is against this background that this paper theoretically investigates the effects of diversification of housing developments in South Africa as a means to promote socio-economic integration in urban human settlements. The paper explains planning and design principles of socio-economic diversity and integration and clarifies the benefits and effects of diversified housing developments for socio-economic integration, especially in urban areas. 


\section{Planning and Design for Socio-economic Diversity and Integration in Urban Housing Developments}

Planning and design are the most important tools towards achieving diversity within human settlements. Good quality of the environment, which is realised through planning and design, supports various economic, social and cultural activities within a society (Ge \& Hokao, 2006; Bailey et al., 2006; Adhvaryu, 2010). However, certain resources such as human, financial and natural resources, among others, are needed to achieve the desired state of our urban environment which is meant to promote diversity. On that note, management of all the necessary resources becomes of importance to diversity of housing developments. Agudelo-Vera, Mels, Keesman \& Rijnaarts (2011: 2296) define resource management as "the conscious handling of natural resources, energy and materials, and the utilization of infrastructure and technology to meet human needs; including extraction, transformation, consumption or use and the disposal of resources. Hence, resource management includes both natural resources and man-made products". In order to effectively and efficiently manage the human, financial and man-made resources, planning and design becomes very important activities in the development of different house types. The aim of planning and design is to achieve set objectives by gathering actions into some orderly sequence (Hall, 2002; Adhvaryu, 2010). For towns and cities, urban planning and design is the key to sustainable human settlements that cater for socio-economic integration.

Urban planning is defined by Hall (2002: 3) as "planning with a spatial or geographical component, in which the general objective is to provide for a spatial structure of activities which, in some way, is better than the pattern that would exist without planning". However, Agudelo-Vera et al., (2011: 2296) defines urban planning as "a sequence of activities aimed to manage spatial development at urban and regional scales considering sociological, economic, political, technological and environmental aspects". Design focuses on control over private and public land-uses and the kinds of buildings allowed, in order to guide spatial layout of capital improvements such as streets, water pipes and sewers (Agudelo-Vera, et al., 2011). The above stated definitions illustrate that there is a strong relationship between resources management and urban planning and design, which can definitely results in diversity and socio-economic integration within housing developments. However, the key issue is to reduce the use of scarce resources and put infrastructure and activities closer to one another in order for people to save on transport costs, fuel, time, and also to reduce pollution.

Theoretically, sustainable diversity has three aspects, namely, economic, social and environmental aspects (Tippett et al., 2007; Agudelo-Vera, et al., 2011). Apart from reaching the set goal, planning and design further promotes new urban forms in response of the social, economic and environmental diversity (Adhvaryu, 2010; Agudelo-Vera, et al., 2011). There is diversity in the economic, social and environmental aspects from local to global levels; however, in most cases problems associated with the economy, social well-being and the environment have a local origin (Capello \& Nijkamp, 2002). Therefore, the role of planning and design is to act as a tool to address the problems. In addition, planning and design should ensure that sustainable human settlements are developed taking into consideration the availability and/ lack-of resources. Watson (2009) is of the view that, in order to achieve sustainable diversity in neighbourhoods, economic, social and environmental issues must be addressed simultaneously and, planning and design must act as key role players in all the processes. Conversely, the use of resources such as land, money, building material, manpower, energy, water and others should be efficient and effective (Council for Scientific \& Industrial Research (CSIR), 2002).

In South Africa, the CSIR (2002) provides a framework on how to achieve sustainable human settlements that promotes diversity and socio-economic integration by adopting the human-centred and the nature-centred approaches. The human-centred approach emphasizes the purpose of planning as to "ensure that the developmental needs and activities of people living in settlements are catered for and, in particular, that opportunities for people to achieve their full potential through their own efforts are maximized (CSIR, 2002: 1). The nature-centred approach on the other hand "recognizes that natural systems interact in highly synergistic ways, which must be respected if breakdowns within them are to be prevented. Therefore, human actions on the landscape must be sensitive to ecological processes". (CSIR, 2002: 1). The purpose of the two approaches is to ensure that development is people-driven and democratic, and, to ensure that there is synergy between man-made and ecological systems, respectively (CSIR, 2002). In this context, according to the CSIR (2002), planning and design must ensure that human settlements use resources efficiently and effectively at all times in order to achieve sustainability, diversity and integration. Therefore, diversified housing developments must generate opportunities which will assist in improving personal welfare from the economic, social, cultural and recreational inputs in the area. Additionally, the plans and designs of urban settlements must be convenient to almost all the human activities.

However, there are a number of physical principles, characteristics, interventions and requirements that need to be taken into consideration when planning and designing urban settlements that promote socio-economic diversity and integration. The quality of the urban structure plays a crucial role in providing favourable conditions for diversity. The 
physical principles, characteristics, interventions and requirements of social and economic diversity within urban housing developments include liveable streets and neighbourhoods; density of residential developments and intensity of land use; and, public spaces that are defined by the built environment and are discussed in the sections to follow.

\subsection{Liveable Streets and Public Spaces in Neighbourhoods}

According to Jacobs \& Appleyard (1978), liveable streets and public spaces in neighbourhoods are clean, safe, have gardens, open spaces and buildings that are well designed and scaled. Public spaces should offer a number of functions that ensures that people are always present and are able to benefit from the spaces (Lima, 2001; Bailey et al., 2006; Adhvaryu, 2010; Salama \& Gharib, 2012; Ramoroka, 2013a, 2013b). Streets and other public spaces should be able to accommodate pedestrians in order to strengthen social cohesion within the neighbourhoods (Jacobs \& Appleyard, 1978; Salama \& Gharib, 2012; Ramoroka, 2013a, 2013b). Furthermore, Montgomery (1998) indicated that streets act as multipurpose spaces where most of the characteristics of neighbourhood life can be observed. The streets, together with other public spaces such as parks, promote surveillance, public social life and social cohesion, amongst others within urban neighbourhoods (Landman, 2012) whereas open spaces provide opportunities for interaction, exchange and public life (Lima, 2012). Therefore, active streets and public spaces promote socio-economic diversity, a sense of belonging and serve as demarcation of public and private spaces within housing developments (Montgomery, 1998; Bailey et al., 2006).

\subsection{Density and Intensity of Developments and Mixed Land Use}

Land use intensity is not only important for diversity but also for housing developments to be self-sustaining. The concentration of people and activities and density are conditions which are necessary for intense use of land which is a requirement for diversity (Montgomery, 1998; Bailey et al., 2006; Salama \& Gharib, 2012; Landman, 2012; Ramoroka, 2013a, 2013b). The variation of density depends on the characteristics of a place and the mixing of activities. However, high densities are a necessity for diversity in urban housing developments and neighbourhoods. Mixed land-uses entail that housing developments and neighbourhoods consist of more than one activity, for example, they are not only residential areas without any other activity. The activities will ensure that people are always present within the housing developments at different times during the day (Bailey et al., 2006; Salama \& Gharib, 2012). Mixed development housing developments have the capability to promote place diversity which ultimately results in sustainable and safe human settlements (Landman, 2012) which supports socio-economic integration. People are attracted to different places because of certain uses such as shops, offices, schools, residences and others and, as a result of the density of people, some practises related to shops, offices and schools are attracted to the same place (Montgomery, 1998; Salama \& Gharib, 2012). Thus, different people are able to use one place for many purposes which in turn support socio-economic integration.

\subsection{Image and Aesthetics}

Diversity can be experienced when different people, spaces and activities are related to one another in terms of how they function within housing developments (Montgomery, 1998; Bailey et al., 2006; Landman, 2012; Ramoroka, 2013a, 2013b). Thus, the image and aesthetics of housing developments contribute to different levels and characteristics of diversity. The use of image and aesthetics in promoting diversity starts with planning and design of housing developments (Bailey et al., 2006; Ramoroka, 2013a, 2013b). How urban planners and designers use different colours, furniture, vegetation and the layout of various spaces and the build environment is very important towards the successful diversification of urban housing developments (Bailey et al., 2006; Landman, 2012). Therefore, badly planned and designed housing developments and neighbourhoods are more likely to compromise the quality of their diversity in the area.

Daily activities should be conducted easily and quickly and the settings of housing developments must improve the lifestyles, increase choices and reduce costs incurred by the population (CSIR, 2002). Equal access to opportunities and facilities within the urban housing developments is very crucial. When planning for and designing housing developments that promote diversity, issues of accessibility must be taken into consideration. One way of achieving accessibility is through connectivity, which can be in the form of transport routes and telecommunication lines. Furthermore, planning and design of housing developments must also emphasis the quality of the place. Standardization should be limited and uniqueness should be promoted in order to enhance sensory qualities in public spaces and places. CSIR (2002: 4) define sensory qualities in public spaces and places as those "which are aesthetically appealing and which add to the quality of 
peoples' lives". Lastly, issues of sustainability must also be considered. The housing developments within urban settlements must work in harmony with the natural settings of the area and they must also be able to accommodate growth and change.

\section{The Benefits of Socio-Economic Diversity in Urban Human Settlements}

Housing developments and neighbourhood choices are related to life events such as moving out of the parents' houses, changing jobs, marriage and specific housing needs, among others (Ge \& Hokao, 2006). Despite the challenges that are faced within housing developments in the quest for diversity, there are a number of benefits that are realised. Diversity plays a very crucial role in influencing people's choices of housing developments and neighbourhoods within towns and cities. People's choices of geographic spaces are encouraged by both the social and economic views (Bailey et al., 2006; Ge \& Hokao, 2006; Gauvin et al., 2013). In addition, the location of different social and income groups is influenced by spatial form, amenities and infrastructure within housing developments (Gauvin et al., 2013). Thus, diversity to some extent is central to people's residential and neighbourhood choices. The following are the factors and/or benefits of diversity that persuade people to choose certain housing developments and neighbourhoods over others. The factors and/or benefits were identified by Jacobs \& Appleyard (1978) and they are liveability; identity and control; access to opportunities, imagination and joy; authenticity and meaning; community and public life; and, an environment for all. These factors and/or benefits are discussed in the sections that follow.

\subsection{Liveability}

According to Jacobs \& Appleyard (1978), diversified urban housing developments should be places where all the people can find residential comfort and satisfaction. These housing developments and neighbourhoods should be safe and peaceful places that can support the raising of children; allow for privacy; and can be used effectively and efficiently to encourage other needs that are associated with being a resident of the areas (Bailey et al., 2006; Ge \& Hokao, 2006; Garba, 2012; Salama \& Gharib, 2012). That is, these urban housing developments and neighbourhoods must be well managed and free of disruptive overcrowding, noise, pollution, crime and other nuisances (Garba, 2012; Jacobs \& Appleyard, 1978). Through the application of liveability principles, socio-economic diversity and integration of urban housing developments and neighbourhoods will then be promoted.

\subsection{Identity and control}

One of the benefits of diversity is the identification and control of urban housing developments and neighbourhoods. As a result of diversity, people are able to control and manage some parts of their environments (Jacobs \& Appleyard, 1978; Bailey et al., 2006; Talen, 2006; Salama \& Gharib, 2012). Furthermore, diversity encourages people to know each other and relate to one other easily (Lima, 2001; Gauvin, 2013). As the same group of people meet regularly for different activities within the same housing developments and neighbourhoods, social cohesion is strengthened. Therefore, people gain control over their housing developments and neighbourhoods as they can identify each other and their different environments very well. However, Talen (2008) argues that diversity of people can promote fear of each other and crime amongst the residents which can result in lack of social cohesion. Thus, in achieving socio-economic integration through diversity, safety issues must be taken into consideration.

\subsection{Access to opportunities, imagination and joy}

Diversity in urban neighbourhoods encourages people to learn from each other, meet new groups of people and adds their life experiences (Jacobs \& Appleyard, 1978; Ge \& Hokao, 2006; Talen, 2006). Furthermore, socio-economic diversity for integration purposes provides different groups of people with a variety of job opportunities; housing developments; and, prospects to share knowledge (Jacobs \& Appleyard, 1978; Garba, 2012; Alraouf, 2012). People in diversified housing developments and neighbourhoods have easy access to economic, health, education and entertainment facilities, amongst others, as they are integrated within their spaces. Thus, most opportunities such as their jobs and facilities for recreation, education and others are at close proximity to their homes regardless of their socioeconomic status. 


\subsection{Authenticity and meaning}

Diversity allows people to understand their housing developments and their neighbourhoods and also be aware of all the opportunities they contain (Jacobs \& Appleyard, 1978; Bailey et al., 2006; Ramoroka, 2013a, 2013c). As compared to the entire town or city which occupies a large geographic scale, housing developments diversity allows for all the residents to familiarize themselves with what their areas offer to them (Jacobs \& Appleyard, 1978; Garba, 2012; Alraouf, 2012). The purpose of all the facilities, amenities, services and infrastructure within housing developments and neighbourhoods is clear to everyone. Diversity avoids spaces which are dominated by one particular group of people as a result of their social, economic and cultural status and accommodates people from different groups (Jacobs \& Appleyard, 1978; Garba, 2012; Alraouf, 2012). Thus, diversity directly supports socio-economic integration within urban housing urban environments.

\subsection{Community and public life}

The structures of the diversified housing developments and urban neighbourhoods encourage community and public life through available amenities, facilities and infrastructure (Jacobs \& Appleyard, 1978; Putnam, 2007; Garba, 2012). Community participation in issues that directly and indirectly affect people is also encouraged within housing developments and neighbourhoods which promote diversity (Putnam, 2007; Garba, 2012). Diversified housing developments and neighbourhoods are able to remove people from their closed private lives into active community and public life (Jacobs \& Appleyard, 1978). Consequently, diversity is able to build strong community relations in matters that concern them, thus strengthening social cohesion. Thus, diversity in urban human settlements serves as a tool for socioeconomic integration in these areas.

\subsection{An environment for all}

Given the nature and characteristics of diversified housing developments and neighbourhoods, these areas are considered to have good environments because most of their spaces which are accessible to all the residents (Bailey et al., 2006; Garba, 2012). According to Jacobs and Appleyard (1978), "good urban design must be for the poor as well as the rich". In addition to different economic groups, good environments must also accommodate people from different cultural and social groups (Lima, 2001; Garba, 2012, Gauvin et al., 2013). Therefore, diversity within urban housing developments can be used to address the apartheid socio-economic segregation which is still experienced within South Africa's towns and cities.

The discussed factors and/or benefits encourage people to choose diversified urban housing developments and neighbourhoods as compared to single land-use areas which accommodate a particular group of people. However, according to Gauvin et al., (2013) people make their residential choices based on their willingness to pay, the level of attractiveness of the different locations and spatial heterogeneous. Thus, diversity for reasons associated with socioeconomic integration in urban areas is one of the major determinants of residential choices.

\section{Legacies and Logic of Segregationist and Apartheid Urban Settlement Planning}

The apartheid spatial fix, which is complex and evidently intractable (Donaldson \& Kotze, 2006; Lemanski, 2006). Social segregation of the apartheid towns and cities was pursued through the Group Areas Act (Act No. 41 of 1950), which created urban settlements along race and ethnic divides (RSA, 2001). Furthermore, this Act prescribed residential spaces in ways that would allow for strict regulation of movements and employment, thereby entrenching fragmentary urban settlement planning, which accentuated and sustained socio-economic inequalities through land-use designs (Charles, 2003). Over years, since the late-1950s, this racially-inspired urban spatial fix came to be firmly frozen into the socioeconomic fabric of the South African society. The racially/ethnically-sensitive zoning mechanisms were incorporated into the general town planning schemes wherein municipalities executed urban settlement legislation with buffers between white and non-white groups (Charles, 2003; Lemanski, 2006). To this extent, urban peripheries were administered in order that they may remain exclusive preserves for black ethnic groups (Charles, 2003), which were virtually socially alienated and denied access of urban amenities, infrastructure and services (Lemanski, 2006). As a result, apartheid urban settlement planning destroyed any sense of shared common nationality amongst the different population groups in South Africa (Lemanski, 2006). Consequently, the majority of black people continue to live in townships that are some distance from the urban centres with deleterious socio-economic implications such as constant daily commuting and 
monthly migratory patterns (Christopher, 2004; Lemon \& Clifford, 2005; Donaldson \& Kotze, 2006). Currently, South African towns and cities remain deeply segregated on the same bases that were established through segregationist and apartheid urban settlement policies. Apparently, the fashionable gated-community village estate approach has merely perpetuated the legacies and logic of segregationist and apartheid urban settlement planning.

South Africa made an attempt to address the challenges associated with socio-economic segregation through the establishment and the adoption of a number of policies which include, among others, the 1997 Habitat Agenda, the 2004 National Housing Plan and Breaking New Ground strategies, and the recent National Development Plan 2030. Notwithstanding all these interventions, the status quo of socio-economically segregated towns and cities has remained intact. Access to these specific estates has continued to exclusively depend upon the command of financial resources because of the profit motif underlying the private sector conduct of business, which leads these settlement development. In Polokwane for example, Thornhill Village and Northview Estate which were developed in the hope of promoting socioeconomic diversification have within them geographically distinct units that are unambiguous manifestations of the class divides in the South African society. In both estates, property values as well as purchase and renting prices are virtually inaccessible to middle and low classes. That is, the private sector owners' form of management, spatial arrangement of the estate and the eager to make profit collude to restrict access to middle and lower socio-economic classes. For this reason, the village estate system has, far from the promise of socio-economic integration, perpetuated settlement segregation in South African towns and cities.

Whereas these estates consist of world-class infrastructure, it does not serve the purposes of socio-economic desegregation, even with the households that manage to access housing therein. The architecture and designs of perimeter fences to sites involve high walls whilst the shared public spaces are reduced to small parks and narrow roads. The existing public spaces, such as parks, which are supposed to promote social integration and cohesion are rarely used by residents. Houses and perimeter walls are built in such a way that neighbours would not have the opportunity to interact with each. Members of different households do not have the opportunity to meet in the public spaces; and, visiting is strictly regulated through calls to the security services. Security measures adopted in these village estates restrict access to neighbours; and, it is practically impossible to visit one another without having permission from the person to be visited through the security office. To this extent, households in abutting properties almost always have no social relations and would not know the surnames of neighbours. Basically, it appears that households who opted for residential property in these estates are primarily motivated by their desire for individualism and security of private spaces. That is to say, the socio-economic desegregation intended through the relevant policy is inconsistent with the private sector owners' and households' reasons for owning and/or renting property therein. The latter appears to be confirmed in the virtual absence of the normal social events that often bring people together; and, these includes weddings, funerals and parties. These social events do not happen in these village estates by management design. To this extent, neighbours in these estate villages are virtual strangers. Even if the middle and lower socio-economic classes where to have access, they would have had no opportunities to meet and spend time with households in other classes because of the form of management, architectural design and, perhaps, deliberate self-selection of the majority of residents therein. It is tenable to argue that the pragmatic effects of the attempts to eradicate the spatial footprints of apartheid city social segregation through the urban integrated estate village model have not borne the desired fruits. Instead, the majority of these planned settlements which are mostly private developments continue to perpetuate the apartheid urban settlement planning. Thus, there is need for nuance thinking about post-apartheid city settlement desegregation because the currents housing developments have in practice failed to achieve their intended purpose.

\section{Towards Diversification of Housing Developments for Socio-economic Integration in Urban Areas of South Africa}

Diversity plays a very important role within housing developments especially in towns and cities. The following are the effects that diversity has on socio-spatial transformation:

- Through mixed developments and land-uses, housing developments diversity reduces racial and ethnic segregation (Bickford-Smith, 1995; Freund, 2001; Lima, 2001; Charles, 2003; Christopher, 2004; Bailey et al., 2006; Donaldson \& Kotze, 2006; Alraouf, 2012; Sharma, 2012; Gauvin et al., 2013; Ramoroka, 2013a, 2013b, 2013c; Gądecki, 2014; Smigiel, 2014). People from different racial and ethnic groups are now able to share residential spaces within towns and cities.

- Housing development diversity further promotes economic variation in terms of activities and accommodating people from different economic backgrounds (Florida, 2002; Bailey et al., 2006; Borsdorf \& Hidalgo, 2008; Landman, 2012; Gauvin et al., 2013, Ramoroka, 2013a). Different economic activities are found and are easily 
accessed within diversified housing developments. Additionally, people are able to work, shop, and do other economic related activities within one geographic space.

- Well-connected built environments can be developed through the use of different building structures, sizes and aesthetics (Gardiner, 1995; Lima, 2001; Hall, 2002; Bailey et al., 2006; Kotus \& Hlawka, 2010; Garba, 2012, Ramoroka, 2013a, 2013b). Thus, people from different socio-economic groups can be accommodated within diversified housing developments.

- In most cases, diversity promotes good city and town planning, design and management (Mabin \& Smith, 1997; Montgomery, 1998; Hall, 2002; Bailey et al., 2006; Talen, 2006; Jacobs \& Appleyard, 2007; Rogers \& Sukolratanametee, 2009; Watson, 2009; Garba, 2012; Musakwa \& Van Niekerk, 2013). In order to achieve diversity within urban housing developments, planning, design and management play a major role.

- Diversity in housing developments is associated with safety and security (Low, 2001; Leisch, 2002; Bailey et al., 2006; Borsdorf \& Hidalgo, 2008; Landman, 2012; Ramoroka, 2013a, 2013b; Zimmerman, 2014 ). Mixed developments and land-uses provide secured environments which are associated with low levels of crime.

However, different people have different perceptions about housing developments and neighbourhoods diversity. Some people are concerned that diversity might compromise the safety and security of their neighbourhoods (Talen, 2008; Zimmerman, 2014). Thus, if people from different economic groups are accommodated within the same housing developments and neighbourhoods, there seem to be high changes of occurrences of crime. Another concern is with regard to access to facilities wherein some people are concerned that the more accessible the facilities are, the more expensive the goods and services rendered in and obtained from the facilities (Lemanski, 2006). The other concern is with regard to the loss of community and public life (Garba, 2012). As people become more diverse, most loose interest in community and public life as they no longer feel comfortable around a group of different people in terms of socioeconomic status. In addition, loss of cultural values is one concern with regard to diversity (Alraouf, 2012; Garba, 2012; Gauvin et al., 2013). Seemingly, neighbourhoods which accommodate people from different cultural groups do not support the prevalence of some cultural values. Contrary to the concerns, diversity in urban housing developments and neighbourhoods can be used as an effective and efficient tool to promote socio-economic integration within the areas.

\section{Conclusion}

This paper explained the planning and design principles of diversity through spatial interventions in order to provide an understanding of how it can be used for socio-economic integration in towns and cities. The principles included liveable streets and neighbourhoods; density of residential developments and intensity of land use; and, public spaces. Seemingly, the application of these principles in planning and designing housing developments ultimately leads to diversity which support socio-economic integration in urban areas. Furthermore, the paper discussed the benefits and effects of diversified housing developments for socio-economic integration especially in urban areas of South Africa. The benefits include liveability; identity and control; access to opportunities, imagination and joy; authenticity and meaning; community and public life; and, an environment for all. Whereas, the effects of diversity for socio-economic integration were identified as the reduction of racial and ethnic segregation; promotion of economic variation; development of wellconnected built environments; stimulation of good city and town planning, design and management; and, the provision of safety and security. The paper then concludes that socio-economic diversity within urban housing developments can be used as strategy to bring together people from different social and economic backgrounds in order to address inequalities that are associated with segregation. However, the preconditions in mixed housing developments which are associated with the management, financial charges and socio-cultural characteristics need to be adjusted in order to give equal opportunity of residence to all the social and economic groups.

\section{References}

Adhvaryu, B. (2010) Enhancing urban planning using simplified models: SIMPLAN for Ahmedabad, India. Progress in Planning, 73, 113207.

Agudelo-Vera, C.M., Mels, A.R., Keesman, K.J. \& Rijnaarts, H.H.M. (2011) Resources management as a key factor for sustainable urban planning. Journal of Environmental Management, 92, 2295-2303.

Alraouf, A.A. (2012) A tale of two souqs: the paradox of gulf urban diversity. Open House International, 37(2), $72-81$.

Baily, N., Haworth, A., Manzi, T., Paranagamage, P. and Roberts, M. (2006). Creating and sustaining mixed income communities: A good practice guide. UK: Chartered Institute of Housing.

Bickford-Smith, V. (1995) South African urban history, racial segregation and the unique case of Cape Town? Journal of Southern African Studies 21(1), 63-78. 
Borsdorf, A. \& Hidalgo, R. (2008) New dimensions of social exclusion in Latin America: From gated communities to gated cities, the case of Santiago de Chile. Land Use Policy, 25, 153-160.

Capello, R. \& Nijkamp, P. (2002) In search of sustainable human settlements: Prefatory remarks. Ecological Economics, 40, $151-155$.

Charles, C.Z. (2003) The dynamics of racial residential segregation. Annual Review of Sociology, 29, 167-207.

Christopher, A.J., (2004) Linguistic segregation in urban South Africa, 1996. Geoforum, 35, 145-156.

Council for Scientific \& Industrial Research (CSIR) (2002) Guidelines for Human Settlement Planning and Design. Pretoria: CSIR.

Denisova, I., Eller,M., Frye, T. \& Zhuravskaya, E. (2012) Everyone hates privatization, but why? Survey evidence from 28 postcommunist countries. Journal of Comparative Economics, 40, 44-61.

Donaldson, R. \& Kotze, N. (2006) Residential desegregation dynamics in the South African city of Polokwane (Pietersburg). Tijdschrift voor Economische en Sociale Geografie, 97(5), 567-582.

Florida, R. (2002) The economic geography of talent. Annals of the Association of American Geographers, 92(4), 743-755.

Freund, B. (2001) Contrasts in urban segregation: a tale of two African cities, Durban (South Africa) and Abidjan (Côte d'Ivoire). Journal of Southern African Studies, 27(3), 527-546.

Gądecki, J. (2014). Reprint of "the wild west. The reality of everyday social relations in gated communities in Poland". Cities, 36, 193199.

Garba, S.B. (2012) Diversity in the public space of a traditional city - Zaria, Nigeria. Open House International, 37(2), 42-52.

Gardiner, J.M. (1995) The use of EIA in delivering sustainable development through integrated water management. International Symposium on Environmental Impact Assessments in Water Management, Bruges, Belgium, May 15-17.

Gauvin, L., Vignes, A. \& Nadal, J. (2013) Modeling urban housing market dynamics: can the socio-spatial segregation preserve some social diversity? Journal of Economic Dynamics \& Control, 37, 1300-1321.

Ge, J. \& Hokao, K. (2006) Research on residential lifestyles in Japanese cities from the viewpoints of residential preference, residential choice and residential satisfaction. Landscape Planning and Urban Planning, 78, 165-178.

Güzey, Ö. (2014). Neoliberal urbanism restructuring the city of Ankara: gated communities as a new life style in a suburban settlement. Cities, 36, 93-103.

Hall, P. (2002) Urban and Regional Planning (4th edn.), London: Routledge.

Jacobs, A. \& Appleyard, D. (2007) Toward an urban design manifesto. Journal of American Planning Association, 53(1), $112-120$.

Kotus, J. \& Hlawka, B. (2010) Urban neighborhood communities organized on-line - A new form of self-organisation in the Polish city? Cities, 27, 204-214.

Kovács, Z. \& Hegedűs, G. (2014). Gated communities as new forms of segregation in post-socialist Budapest. Cities, 36, $200-209$.

Landman, K. (2012) Urban space diversity in South Africa: Medium density mixed developments. Open House International, 37(2), 5362.

Leisch, H. (2002) Gated communities in Indonesia. Cities, 19(5), 341-350.

Lemanski, C. (2006) The impact of residential segregation on social integration: evidence from South African Neighbourhood. Geoforum, 37, 417-435.

Lemon, A. \& Clifford, D. (2005) Post-apartheid transition in a small South African town: Interracial property transfer in Margate, KwazuluNatal. Urban Studies, 42, 7-30.

Lima, J.J. (2001) Socio-spatial segregation and urban form: Belém at the end of the 1990s. Geoforum, 32, 493-507.

Mabin, A. \& Smit, D. (1997) Reconstructing South Africa's cities? The making of urban planning 1900-2000. Planning Perspectives, 12, 193-223.

Montgomery, J. (1998) Making a city: urbanity, vitality and urban design. Journal of Urban Design, 3(1), 93-116.

Musakwa, W. \& Van Niekerk, A. (2013) Implications of land use change for the sustainability of urban areas: a case of Stellenbosch, South Arica. Cities, 32, 143-156.

Putnam, R.D. (2007). "E Pluribus Unum: Diversity and Community in the twenty-first century", Scandinavian Political Studies, 30(2), 137174.

Ramoroka, T. (2013a) Building safer urban human settlements in South Africa: a case of the National Development Plan 2030. Journal of Public Administration 48(2), 321-333.

Ramoroka, T. (2013b) Safety and fear of crime in built environments: role of municipalities and community participation in South Africa. In Sebola, M.P., Tsheola, J.P., Phago, K.G. \& Balkaran, S. (eds.). The Challenges of Local Government in South Africa. Pretoria: SAAPAM.

Ramoroka, T. (2013c) Land use management policies and small businesses within South Africa's cities. In Delener, N., Fuxman, L., Lu, F.V. \& Rivera-Solis, L.E. (eds.). Globalizing Businesses for the Next Century: Visualizing and Developing Contemporary Approaches to Harness Future Opportunities. New York: GBATA.

Republic of South Africa (RSA), (2001) White Paper on Spatial Planning and Land Use Management. Pretoria: Government Printers.

Rogers, G.O. \& Sukolratanametee, S. (2009) Neighborhood design and sense of community: Comparing suburban neighborhoods in Houston Texas. Landscape and Urban Panning, 92, 325-334.

Salama, A.M. \& Gharib, R.Y. (2012) A perceptual approach for investigating urban space diversity in the city of Doha. Open House International, 37(2), 24-32.

Sharma, M. (2012) A geographic perspective on intra-urban racial/ethnic diversity, segregation, and clustering in Knoxville, Tennessee: 1190-2000. Applied Geography, 32, 310-323.

Smigiel, C. (2014). Reprint of "the production of segregated urban landscapes: a critical analysis of gated-communities in Sofia". Cities, 
36, 182-192.

Talen, E. (2006). "Design that enables diversity: the complications of a planning Ideal", Journal of Planning Literature, 20(3), $233-249$.

Talen, E. (2008). Design for diversity: Exploring socially mixed neighbourhoods. Boston: Architectural Press.

Tippett, J., Handley, J.F. \& Ravetz, J. (2007) Meeting the challenges of sustainable development-A conceptual appraisal of a new methodology for participatory ecological planning. Progress in Planning, 67, 9-98.

Todes, A., Karam, A., Klug, N. \& Malaza, N. (2010) Beyond master planning? New approaches for spatial planning in Ekurhuleni, South Africa. Habitat International, 34(4), 414-420.

Watson, V. (2009) 'The planned city sweeps the poor away': urban planning and the $21^{\text {st }}$ century urbanization. Progress in Planning, 72 , 151-193.

Zimmerman, P.R. (2014). The deterrence of crime through private security efforts: theory and evidence. International Review of Law and Economics, 37, 66-75. 